\title{
ARCHAEOBOTANY IN GREECE
}

Alexandra Livarda, Department of Archaeology, University of Nottingham, UK

The final version of this paper can be found in the following publication:

Livarda, A. 2014. Archaeobotany in Greece. Archaeological Reports 60: 106-116.

This paper provides a brief overview of the history and the main achievements of archaeobotanical work in Greece to date, with the aim of highlighting its potential and creating a framework in which future work can be contextualised. The term 'archaeobotany' is used here in its narrow sense, referring to the study of plant macroremains, such as seeds, fruits and other plant parts, and excluding charcoal studies or 'anthracology' and analyses of microremains (e.g. pollen, phytoliths), which have developed to become separate sub-disciplines.

\section{From the first finds to a science}

Plant remains in the form of large concentrations of seeds, or individual finds of large specimens (known as spot finds), such as fruit stones, have been reported in the archaeological literature since the end of the nineteenth century. Botanical specimens that were occasionally unearthed caught the attention of archaeologists and site directors, who would either invite botanists or other experts to identify the species, or would simply rely on the expertise of the archaeological team, including that of local workers. A rather widely reported case is that of the early excavations at Knossos, where local workmen identified seeds found in a pithos as 'Egyptian beans', a variety of small fava beans imported to Crete from Alexandria at the end of the nineteenth century (Evans 1901, 20-21). At the other end of the spectrum, Schliemann (1886, 93), for instance, sent samples of the masses of burnt grains encountered in the early levels of Tiryns to an expert, Professor L. Witmack, who securely identified them as grape pips albeit of 'unusual size'. K.F. Vickery was the first to review plant finds, among other lines of evidence, in his book 'Food in Early Greece' (published in 1936), in his attempt to reconstruct past diets. Archaeobotanical spot finds continued to be reported in the archaeological literature until relatively recently, with Zois' (1992) publication on Early Minoan Vasiliki Ierapetras, for example, providing the latest such report from Crete (see Livarda and Kotzamani 2014, 7).

A reference list of several spot finds was compiled by Megaloudi $(2006,5)$ in the publication of her PhD thesis. More recently Livarda and Kotzamani $(2014,5-7)$ have analysed and reviewed all spot finds from Neolithic and Bronze Age Crete by phase and publication date, drawing attention to the potential problems, and often unreliability, of these early reports. Despite such potential problems, plant finds visible to the naked eye aroused curiosity and paved the way towards their more systematic collection in the following decades.

Archaeobotany, the study of plants in cultural settings, similarly to all other bioarchaeological sub-disciplines, became a recognised field in archaeology with the emergence of 'New Archaeology' in the 1970s. In this context, new methodologies and analytical tools were developed for the recovery and interpretation of botanical remains, which allowed their potential application in research questions, instead of 
species merely being listed in reports. The development of the flotation machine for the bulk recovery of organic remains was perhaps the first important step in this direction. Based on the water-separation principle, D.H. French (1971) devised a machine, commonly known as the 'Ankara machine', during the excavation of Can Hasan III in Turkey, of which several variations exist nowadays (Figure 02). Hansen was the first to employ this technique in archaeology in Greece for the recovery of plant remains at Franchthi Cave in the 1970s (see e.g. Hansen 1991), although Jane Renfrew had already employed bucket flotation for the same purpose in the 1960s. Since then, the employment of archaeobotanists in research projects and in the field, the incorporation of targeted sampling strategies, and the more efficient recovery of plant remains, allowed the accumulation of a reliable and controlled corpus of plant finds from archaeological sites in Greece, which has contributed to the illumination of several aspects of life in the past.

\section{The interdisciplinary basis}

Archaeobotany, as implied by its name, is inherently inter-disciplinary. Botany, however, is but one of the several disciplines married together in the study of plants in past societies. Ethnographic and experimental investigations have been two of the foundation stones of archaeobotany. More recently, genetics, stable isotope analysis, and GIS modelling have added to and enriched its interpretative potential. A full review of archaeobotanical practice is beyond the scope of this essay, however, some reference to seminal inter-disciplinary work conducted in Greece, within the context of archaeobotany, is necessary to understand current research directions.

Greece still hosts pockets of rural communities that are operating in largely traditional agricultural and farming systems, and are thus conducive to ethnographic work. The Aegean islands of Amorgos and Karpathos are such examples, and this is where early research by Glynis Jones and Paul Halstead focused. Careful observations, discussions with local people, and collection of plant material from different agricultural activities and their separate stages, helped formulate models for the interpretation of archaeobotanical assemblages. In order to decipher what plant remains 'mean', it was first crucial to understand how plants came to be together in one sample. The premise was that, without modern machinery, cereals and legumes after harvesting needed to pass through a series of stages, such as threshing, winnowing, coarse and fine sieving, and hand cleaning, in various combinations, to be ready for consumption/usage (e.g. Hillman 1981). By studying the relative proportions of modern free-threshing grains, chaff, and weeds, from each step in this sequence, models were developed that allowed identification of the crop processing stage from which an archaeological plant assemblage was derived (e.g. Jones 1990). This method could only be applied, however, to the same kinds of crops, i.e. freethreshing, as different types of cereals, such as glume wheats, require a different set of stages for their processing. Analogies, therefore, to non free-threshing crops are not valid.

To overcome this problem, G. Jones $(1984,1987$ a) resorted to the qualities of the weed species, and found that the most relevant factors in the processing of crop grains was their size (small or big); their tendency to remain in heads or not (free or headed); and their aerodynamic properties (light or heavy). After collecting weeds from both the product and the by-product of each crop processing stage, G. Jones classified them into groups according to the abovementioned qualities, to indicate which processing 
stage they belonged to. In this manner she managed to avoid the inclusion of chaff in the model, which dictates the processing of different types of crops, and thus, in the previous model, prevented analogies to be drawn to different types of crops. The application of this method of analysis to archaeological plant material opened new possibilities towards disentangling all types of past crop assemblages. The importance of both models for the crop processing stage identification is that together they provide a better understanding of agricultural formation processes and allow comparisons of material from the same stage, without obscuring other patterns (see, Jones 1991).

Following a similar rationale, Evi Margaritis and Martin Jones (2008a), prompted by the sheer quantities of charred olive remains recovered at the Hellenistic farmhouse of Tria Platania in Pieria (fourth to second centuries BC), combined experimental and ethnographic studies to suggest how olives were consumed (as fruits or for the production of olive oil) and how to identify the different processing stages of this crop. In the same study they also offered insights into possible crushing techniques for the extraction of oil. The authors indicated the different proportions of whole and fragmented olives, 'pulp', flesh and kernels that should be present in each processing stage, and proposed a method of identifying whether olive stone fragments were broken before or after deposition into the archaeological layer. On the basis of this work, and of related evidence, olive-oil production using a technique that did not involve complete crushing of all olives during milling has been inferred in the aforementioned Hellenistic site of Tria Platania (Margaritis and Jones 2008b). Similarly, olive-oil production has been suggested for the Protogeometric/Early Greek site North of the Little Palace, Knossos (Livarda 2008), and at the Archaic city of Azoria in Crete (Haggis et al. 2011), among other sites.

A good deal of ethnographic work has been carried out in Greece and has contributed significantly to our appreciation of the husbandry practices and agricultural regimes of the past (Figure 03). Some fundamental studies with direct relevance to archaeobotany are, for instance, the work by Jones and Halstead (1995) and Halstead and Jones (1989) that shed light on the complexity of farmers' choices in regard to what to plant, how and when to process different crops, and what to use as food or fodder, according to need and the success or failure of each year's yield. This year (2014), Paul Halstead's new book 'Two Oxen Ahead' was published, where he summarised more than 30 years of research, first-hand experience, and deep knowledge of traditional farming systems in Greece and the wider Mediterranean. This excellent book is an invaluable tool for archaeobotanists and other interested readers. It demonstrates successfully how an in-depth understanding of current farming practices can be a key to deciphering the past.

Ethnographic work has been complemented by rigorous botanical research, including weed ecology (e.g. Bogaard 2002; Jones 1992a, 2002; Jones et al. 2010), which has significantly contributed to the 'translation' of archaeobotanical data into reconstructions of past crop husbandry regimes. The premise is that although crops can adapt to different environments through human manipulations, weeds are sensitive ecological indicators that will colonise a field only when conditions are favourable to their particular requirements. Therefore, they can act as indirect indicators of specific soil conditions. It is, thus, possible to provide insights into irrigation regimes; the application or not of manuring, so as to increase soil fertility; 
fallow and crop rotation practices; seasonality of cultivation; intensive or extensive agriculture regimes, and so on. These practices are directly associated with the organisation of life in the past and have implications for wider questions concerning different strategies, from self-sufficiency to surplus production and further redistribution of plant-based products, as well as other aspects of socio-cultural, economic and political relations and decisions. The application of weed ecology to the investigation of husbandry practices is regularly employed in Greek archaeobotany, albeit with various results according to the presence, the quality and quantity of weeds in the assemblages.

Stable isotope studies are increasingly been employed in archaeobotanical research to address similar issues, using the crop itself instead of its weeds (e.g. Bogaard et al. 2007; Ferrio et al. 2005; Fraser et al. 2011). Two applications can be mentioned here to illustrate how this method has added to our understanding of the prehistory of Greece. The first, by Heaton et al. (2009), involved the study of carbon stable isotopes of modern and archaeological cereal remains from the storerooms unearthed at the Bronze Age site of Assiros Toumba in North Greece. The results indicated that cereals were cultivated under an intensive horticultural regime, possibly with some watering. They verified that emmer and spelt were grown together as a maslin crop (i.e. grown intentionally together in one field), and indicated that, in all likelihood, the produce was stored after pooling a single year's local harvests. This mobilisation of resources was interpreted as indicative of either communal storage, or of a central authority orchestrating the grain collection, which was consistent with the rather localised settlement hierarchies of the period in the area.

The second study integrated carbon and nitrogen stable isotope analysis of plants and animals, and collagen sequencing of sheep and goats to reconstruct farming practices at Kouphovouno, a middle to late Neolithic tell village in the Peloponnese, near Sparta (Vaiglova et al. 2014). A nuanced picture of Neolithic agricultural practices at the site was achieved, supporting the model of small-scale mixed agriculture and settlement organization, highlighting changes of crop and animal practices through time, such as a reduction in the scale of ovicaprid management and a decrease in manuring and in the labour involved during the Late Neolithic phase.

This brief overview has highlighted some of the basic current archaeobotanical approaches and methods, and their interdisciplinary nature, whilst also providing examples of their applications in archaeology in Greece. The next section goes through specific research themes to showcase research trends in the archaeobotany of Greece.

\section{Selected research themes in Archaeobotany of Greece}

Archaeobotanical research in Greece has largely focused on prehistory and it is only recently that some timid steps have been made towards its incorporation in the research of the later periods. The customary lack of sampling for all bioarchaeological remains in excavations of sites dating to historic periods complicates the situation further, as normally there is not even a backlog in storage that can be revisited and studied. As a result, the bulk of the research themes addressed here refers mainly to earlier periods. 
One of the most intensively researched topics worldwide is that of the emergence of agriculture and early farming communities. A long-standing debate with regard to this period in Greece focuses on whether agriculture and its associated lifestyle developed mainly through indigenous processes, or was transferred from western Asia through the movement of people and/or ideas (see e.g. Kotsakis 2001). Central to this debate is also the investigation of the character of human habitation and lifestyles in the Palaeolithic and Mesolithic periods, which set the scene for the changes that followed in the Neolithic. Archaeobotany's contribution to this debate, although still relatively limited, is of particular significance, as it offers primary evidence for foraging and the emergence of an agricultural way of life (for a review see Valamoti and Kotsakis 2007). The first site where targeted soil sampling for the recovery of plant remains from these early periods was conducted was at Franchthi cave in the Peloponnese, spanning the period from the Upper Palaeolithic to the Neolithic (e.g. Hansen 1991). The data from Franchthi cave provided significant insights into early dietary regimes and foraging practices, and indicated the early use of wild barley and oat in the later phases of the Upper Palaeolithic period (ibid.). On the basis of material from the whole time sequence, Hansen (1991, 1999, 160-3) favoured the idea of the introduction of fully domesticated plants through exogenous influences, with the settling of new people in the area, although she did not rule out the possibility of some earlier, indigenous wild plant cultivation through experimentation.

Since this research was carried out, a few more sites have yielded archaeobotanical material dated to these early periods. In 2010, Georgia Kotzamani completed her $\mathrm{PhD}$ thesis 'From gathering to cultivation', which added significant new data and interpretations of these elusive periods (Palaeolithic, Mesolithic and early Neolithic), presenting the archaeobotanical assemblages from the sites of Theopetra cave in Thessaly, Schisto cave in Attica, Revenia in Macedonia and Sidari in the island of Corfu. The archaeobotanical data from Theopetra, the study of which was initiated by Maria Mangafa (whose demise has been a great loss), are particularly important as they provided the first evidence of human-plant interactions during the end of the middle Palaeolithic period. Kotzamani's study contributed to the delineation of a much more nuanced picture of early plant use in Greek territory and showed that the pattern of the adoption of agriculture was quite heterogeneous. She argued against the sudden introduction of all domesticates as a package from the near East and suggested that, although certain introductions seem to have taken place (e.g. emmer wheat), local, long-term knowledge of several available wild plant progenitors (e.g. of barley and vetchling) could also have contributed to cultivation, and the eventual domestication, of some of these. Her study thus approached the transition to agriculture as a multifaceted process that involved the incorporation of different elements towards the domestication of the landscape, moving away from onedimensional explanations for the emergence of agriculture in the space of modern Greece. More studies of these periods are gradually being published, which will fill in the gaps towards a better understanding of early human lifestyles.

Much more archaeobotanical work has been conducted on the ensuing Neolithic phases and the Bronze Age period. The work of Anaya Sarpaki, the first professionally-trained Greek archaeobotanist, and of Soultana Maria Valamoti, has been key to the investigation of these periods in southern (mainly Crete) and northern Greece respectively. For northern Greece, the publication of Valamoti's first monograph (2004), where she presented an archaeobotanical analysis of five Late 
Neolithic and Early Bronze Age sites from the area, was a significant milestone. The material subjected to analysis was drawn from the extensive sites of Makriyalos and Arkadikos, and the tells of Mandalo, Dikili Tash and Makri. Her careful examination indicated that the plant remains did not cluster according to settlement type (whether of the extensive or tell forms), but the observed patterns were instead related to the types of deposits (refuse versus storage). In each site different practices were identified, delineating a rich mosaic of dietary regimes, plant selection, animal feeding strategies, certain fuel choices, and other aspects of crop and animal husbandry practices. Several other archaeobotanical studies have been conducted in northern and central Greece, which have helped shape our understanding of the character of prehistoric economies and societies in the area. As far as the Neolithic period is concerned, most of the studies refer to the Late Neolithic phase, but there is also a substantial dataset for the Middle Neolithic.

At the opposite end of the Balkan peninsula, in southern Greece, far fewer studies of Neolithic archaeobotanical assemblages have been assembled and most of them are reports from older excavations (e.g. Lerna - Hopf 1961; Saliagos - J. Renfrew 1968, Keos/Kephala - J. Renfrew 1977). Of particular interest is the material from Neolithic Knossos, as it constitutes the earliest and the richest assemblage from Crete, covering all Neolithic phases starting with the Aceramic. The only other Neolithic archaeobotanical assemblage available to date from the island is that from the site of Kephala Petras in east Crete, dated to the Final Neolithic, which is currently under the study of Georgia Kotzamani, and is reported in Livarda and Kotzamani (2014). The Knossos assemblage was first studied by Hans Helbæk and later revisited by Anaya Sarpaki, who published the full study in 2009. Sarpaki (2009) suggested that the people who settled at Neolithic Knossos were fully-fledged farmers, well acquainted with agricultural practices, and who used a wide range of crops, including various cereals, legumes, fruits and oil producing plants, in a mixed agricultural, horticultural and probably arboricultural regime. Of significance also has been the identification of free-threshing wheat in substantial quantities already in Aceramic levels, rendering this one of the earliest finds in Greece. Taking also into account its limited occurrence in northern Greece (see below), this find was interpreted as an indication of eastern connections and of the importation of free-threshing varieties of wheat from western Asia.

Overall, the archaeobotanical studies now available for the Neolithic period across Greece have highlighted variability between sites, but also reflect certain patterns, including a geographical distinction, between north and south. Although currently most data derive from northern Greece, it seems that einkorn wheat predominated in the north and emmer and possibly free-threshing wheat in the south. This pattern continued into the Bronze Age, although free-threshing wheat became more common in the north too (see, e.g. Valamoti 2009, 120-1). The einkorn prevalence in northern Greece has been explained by Sarpaki, prompted by her work on the Neolithic Toumba Balomenou in Chaironeia (1995), as some form of cultural traditionalism. Valamoti $(2004,111-15 ; 2009,50-1)$ also concurred that it could be related to cultural preferences and to the identity of local people.

Several culinary changes, among other plant-related activities, have been observed for the Bronze Age of Greece. The Bronze Age is in fact one of the best-documented periods across Greece in terms of archaeobotanical research. Various new food plants 
were added to the dietary repertoire during this period, according to the archaeobotanical literature. Research and the careful examination of plant material by G. Jones and Sarpaki, for instance, have indicated the occurrence in Bronze Age assemblages for the first time in Greece of two new species: Cyprus vetch (Lathyrus ochrus) (Jones 1992b) and Spanish vetchling (Lathyrus clymenum) (Sarpaki and Jones 1990), the former was identified at the Unexplored Mansion at Knossos and the latter at Akrotiri, on Thera/ Santorini. More finds of these legumes have been unearthed since their first identification, but so far they all derive from Crete, possibly another indication of their southern distribution and the tight links between this island and Santorini (Livarda and Kotzamani 2014, 12). Legumes, in general, constituted a significant part of prehistoric diet and agriculture. Their role (despite the apparent absence of relevant references in Linear B tablets) has been stressed by several scholars, with Sarpaki (1992) arguing that legumes should be added to the traditional Mediterranean triad (cereals, olives, grapes).

Another change that crystallised in the Bronze Age was the establishment of two more cereals: spelt and broomcorn millet. Their exploitation is certain for northern Greece, whereas only a few such finds have been reported from southern areas, where in fact the occurrence of millet is not fully verified (Valamoti 2009, 53; Livarda and Kotzamani 2014, 11). Valamoti (in press), combining archaeobotanical, zooarchaeological, artefactual and human isotopic data, pinpointed the establishment of millet to the Late Bronze Age and suggested that its consumption was restricted to specific regions, settlements or individuals. Notably, she further proposed a possible link between the introduction of millet and the horse in northern Greece, through contacts with horse breeding cultures from the north and/or the northeast that based their subsistence on this crop. One of the most promising current research trends in archaeobotany is indeed the exploration of connectivity networks and their implications for the intertwining of people, their ideas and practices, as prompted by the analysis of plant remains. Another example of this trend is the work of Jones and Valamoti (2005), who identified a new oil-producing plant of the genus Lallemantia in archaeobotanical assemblages of northern Greece and investigated its origin and distribution, as it is not native to the area. The two researchers concluded that Lallemantia seeds were probably introduced through an eastern or northern route during the early Bronze Age and were taken up in local cultivation. On the basis of the timing of its introduction, a link has been suggested between the distribution networks of Lallemantia and those of raw materials for metallurgy (e.g. Valamoti 2009, 124). This discovery opens up new possibilities for the combination of archaeobotanical and archaeometallurgical investigations, towards a better understanding of trade and the movement of people, products and ideas (Jones and Valamoti 2005).

Archaeobotanical research of the Bronze Age has identified the introduction of several other plants from different parts of the world that enriched life in different ways during this period. The culinary journey from the emergence of agriculture to the Bronze Age on the basis of archaeobotanical remains is summarised in Valamoti's second monograph, which was published in Greek in 2009. This is a very well written and well informed textbook, providing useful insights into prehistoric diet and cuisine in Greece, their development and changing roles in society, and concluding with a comprehensive bibliography and summary figures and tables of the available archaeobotanical data. Earlier (and more brief) studies on agriculture, plant 
management and their role in socio-economic organisation in prehistoric Greece were published by G. Jones (1987b) and Hansen (1988). More recently, two accounts were published specifically covering the prehistory of Crete, one by Sarpaki (2012a) focusing on the Neolithic and the role of certain fruits, and one by Livarda and Kotzamani (2014) that synthesised and assessed all archaeobotanical remains to date.

Within the rich reservoir of prehistoric archaeobotanical research that has accumulated to date, there is a final theme that needs to be highlighted, one which has occupied substantial space in the publication record, namely the exploitation and roles of grapes, olives and their by-products. Debates around their knowledge and use started in the 1970s, when Colin Renfrew (1972) introduced the idea that oleiculture and viticulture (along with cereal cultivation) created the conditions for the emergence of the Bronze Age palatial elite and the need for redistribution centres for these products and their by-products. Archaeobotanists and other archaeologists, employing plants among other lines of evidence, have contributed to the debate over more than 40 years. One of the most influential arguments was put forward by Hamilakis (e.g. 1996, 1999), who on the basis of plant, artefactual, documentary, ethnographic and historical evidence suggested that wine and olive oil were employed and consumed in power negotiation by social élites (the reproduction and legitimisation of authority). He also identified their systematic exploitation in the first- and second-Palace Periods on Crete (the later Bronze Age) respectively, and argued that oil production had intensified in the post-palatial period (contra C. Renfrew 1972). In this context, the olive and vine were not seen as subsistence crops, but rather as luxury products.

Archaeobotanical data for olive cultivation indicates a very restricted presence in northern Greece and a more widespread occurrence in the south, where it seems to have been established sometime during the Bronze Age (see, e.g. Hansen 1988; Valamoti 2009, 88; Sarpaki 2003, 2012a). The earliest archaeobotanical evidence for the production of olive oil derives from the Middle Minoan IA site at Chamalevri in Crete (Sarpaki 1999). On the other hand, grapes (Figure 04) are present across Greece from the Neolithic period onwards and there is good evidence for wine production already in this period in the north. Research by Valamoti and others (2007) on the Neolithic tell site of Dikili Tash in eastern Macedonia unearthed charred grape remains, dated to the second half of the fifth millennium $\mathrm{BC}$, which were interpreted as grape juice and/or wine-pressings. These form the earliest such evidence in the Aegean to date. As more and more archaeobotanical data, along with other lines of evidence, have becoming available over recent years, interest in the role of these plants in past societies and economies has been maintained (e.g. Livarda and Kotzamani 2014; Margaritis 2013; Sarpaki 2012a, 2012b). The wealth of new data, resulting from new excavations and palaeoenvironmental projects, and the application of new methodologies, such as residue analysis, has brought optimism that new interpretations can be reached, but also, some scepticism. Sarpaki (2012a, 41), for instance, raised concerns about the potential misinterpretations of organic residue analysis, stressing that they often 'indicate one of several substances, without being able to pinpoint exactly which one it is'. Despite the existing problems, critical and careful usage of all evidence has great potential for further positive contributions to these archaeological debates. 
Many more research topics have been addressed in the context of prehistoric archaeobotany, such as the identification of cooked food and different cooking methods, the identification and role of fodder and dung, and so on. In contrast, research conducted on subsequent periods of the past is less advanced. Megaloudi (2006) has compiled a list of sites and plant species in Greece from the Early Neolithic to the Classical period, which includes dedicated sections on the Protogeometric, Geometric, Archaic and Classical periods. This study is very useful as a starting point in the investigation of what plants were available (although the reader is recommended to consult the original sources for fuller pictures of the individual studies and the quantified data cited in them). The Iron Age is somewhat better understood and Helmut Kroll (2000) has provided a useful overview of the archaeobotanical information on agriculture and arboriculture of this period in mainland Greece. One of the changes that Kroll observed was the overall predominance of free-threshing to glume wheat, which has several implications for contemporary patterns of socio-economic organisation. Livarda more recently (2012) reported on new plant evidence from Crete, dated to the Protogeometric period, along with which she provided an overview of all archaeobotanical data from Greece for this phase. This study identified contextual and spatial differences in the use of various plants and suggested that the character of the archaeobotanical data of the period, on current evidence, resembles Bronze Age assemblages more closely than later Iron Age ones, as described by Kroll (2000).

The evidence for later periods is more sporadic and archaeobotanical work consists mainly of site-specific studies (e.g. Bookidis et al. 1999; Kroll 1993). Some interesting insights, nevertheless, have been obtained on plants in ritual practices. Megaloudi (2005), for instance, studied the charred plant remains from a sacrificial enclosure inside a heroon at Messene, in the Peloponnese, dated to the end of the third century BC, and reported the first macrobotanical evidence for the presence of chestnut in Greece. In this study Megaloudi also reviewed all other evidence of plant offerings from Classical and Hellenistic Greece, and compared them to those from Archaic and Roman Italy and central Europe, and the Roman Empire in general. She concluded that, as to other areas where such research has been conducted, there were no significant differences between the food plants of the dead and of the living, and that chestnut and stone pine had a clear, although not exclusive, association with ritual practices.

\section{Epilogue}

This account of archaeobotanical work in Greece is by no means exhaustive. The body of work is very rich, particularly for the prehistoric periods, and here only a selection was reported to highlight the general history and main research directions of the field. Most individual studies, often published as parts of site reports, are cited and summarised in the various synthetic studies mentioned in the text. Archaeobotany has covered a great distance since its first applications. It is a sub-discipline that has now started becoming recognised as an important aspect of archaeological research; an aspect that has great potential to both add to discussions and commence new debates about life in the past. A great deal more data and archaeobotanical research is necessary to fully understand the complex nature of human-plant interactions throughout history. Such a task entails close collaboration and integration of archaeobotany, as well as cognate lines of evidence, into the research design of 
excavation projects from their inception; a promising trend that has started in the archaeology of Greece.

\section{References}

Boggard, A. (2002) 'Questioning the relevance of shifting cultivation to Neolithic farming in the loess belt of Europe: evidence from the Hambach Forest experiment', Vegetation History and Archaeobotany 11, 155-68

Bogaard, A., Heaton, T.H.E., Poulton, P., Merbach, I. (2007) 'The impact of manuring on nitrogen isotope ratios in cereals: archaeological implications for reconstruction of diet and crop management practices', Journal of Archaeological Science 34, 335-43

Bookidis, N., Hansen, J., Snyder, L., and Goldberg, P. (1999) 'Dining in the Sanctuary of Demeter and Kore at Corinth', Hesperia 68, 1-54.

Evans, A.J. (1901) 'Knossos. Summary report of the excavations in 1900 I. The Palace', Annual of the British School at Athens 6, 3-70

Ferrio, J.P., Araus, J.L., Buxó, R., Voltas, J. and Bort, J. (2005) 'Water management practices and climate in ancient agriculture: Inference from the stable isotope composition of archaeobotanical remains', Vegetation History and Archaeobotany 14, $510-7$

Fraser, R.A., Bogaard, A., Heaton, T., Charles, M., Jones, G., Christensen, B.T., Halstead, P., Merbach, I., Poulton, P.R., Sparkes, D. and Styring, A.K. (2011) 'Manuring and stable nitrogen isotope ratios in cereals and pulses: Towards a new archaeobotanical approach to the inference of land use and dietary practices', Journal of Archaeological Science 38, 2790-804

French, D.H. (1971) ‘An Experiment in Water Sieving', AnatSt 21, 59-64

Haggis, D.C., Mook, M.S., Fitzsimons, R.D., Scarry, C.M., Snyder, L.M. and West III, W.C. (2011) 'Excavations in the Archaic Civic Buildings at Azoria in 20052006', Hesperia 80(1), 1-70

Halstead, P. (2014) Two Oxen Ahead. Pre-Mechanized Farming in the Mediterranean (Chichester, Oxford)

Halstead, P. and Jones, G. (1989) 'Agrarian ecology in the Greek islands: time stress, scale and risk', Journal of Hellenic Studies 109, 41-55

Hamilakis, Y. (1996), 'Wine, Oil and the Dialectics of Power In Bronze Age Crete: a Review of the Evidence', Oxford Journal of Archaeology 15(1), 1-32

Hamilakis, Y. (1999) 'Food technologies/technologies of the body: the social context of wine and oil production and consumption in Bronze Age Crete', World Archaeology 31, 38-54 
Hansen, J.M. (1988) 'Agriculture in the prehistoric Aegean: Data versus speculation', American Journal of Archaeology 92, 39-52

Hansen, J.M. (1991) 'The Palaeoethnobotany of Franchthi Cave', in T.W. Jacobsen (ed) Excavations at Franchthi Cave (Bloomington and Indianapolis) Fascicle 7

Hansen, J. (1999) 'Franchthi Cave and the beginnings of agriculture in Greece and the Aegean', in P.C. Anderson (ed) Prehistory of Agriculture. New Experimental and Ethnographic Approaches (Monograph 40, Los Angeles) 156-67.

Heaton, T.H., Jones, G., Halstead, P. Tsipropoulos, T. (2009) 'Variations in the $13 \mathrm{C} / 12 \mathrm{C}$ ratios of modern wheat grain, and implications for interpreting data from Bronze Age Assiros Toumba, Greece', Journal of Archaeological Science 36, 222433

Hillman, G. (1981) 'Reconstructing crop husbandry practices from charred remains of crops', in R. Mercer (ed) Farming Practice in British Prehistory (Edinburgh) 123-63

Hopf, M. (1961) 'Pflanzenfunde aus Lerna/Argolis', Der Züchter 31(5), 239-47

Jones, G. (1984) 'Interpretation of archaeological plant remains: ethnographic models from Greece', in W. van Zeist and W.A. Casparie (eds), Plants and Ancient Man (Rotterdam) 43-61

Jones, G. (1987a) 'A statistical approach to the identification of crop processing', Journal of Archaeological Science 14, 311-23

Jones, G. (1987b) 'Agricultural practice in Greek prehistory', Annual of the British School at Athens 82, 115-23

Jones, G. (1990) 'The application of present-day cereal processing studies to charred archaeobotanical remains', Circaea 5(2), 91-6

Jones, G. (1991) 'Numerical analysis in archaeobotany', in W. van Zeist, K. Wasylikowa and K.-E. Behre (eds) Progress in Old World Palaeoethnobotany (Rotterdam) 3-80

Jones, G. (1992a) 'Weed phytosociology and crop husbandry: identifying a contrast between ancient and modern practice', Review of Palaeobotany and Palynology 73, $133-43$

Jones, G. (1992b) 'Ancient and modern cultivation of Lathyrus ochrus (L.) DC. in the Greek islands', Annual of the British School at Athens 87, 211-17

Jones, G. (2002) 'Weed ecology as a method for the archaeobotanical recognition of crop husbandry practices', Acta Palaeobotanica 42, 185-93

Jones, G., Charles, M., Bogaard, A. and Hodgson, J. (2010) 'Crops and weeds: the role of weed functional ecology in the identification of crop husbandry methods', Journal of Archaeological Science 37, 70-7 
Jones, G. and Halstead, P. (1995) 'Maslins, mixtures and monocrops: on the interpretation of archaeobotanical crop samples of heterogenous composition. Journal of Archaeological Science 22, 103-14

Jones, G. and Valamoti, S.M. (2005) 'Llalemantia, an imported or introduced oil plant in Bronze Age northern Greece', Vegetation History and Archaeobotany 14, $571-7$

Kotsakis, K. (2001) 'Mesolithic to Neolithic in Greece. Continuity, discontinuity or change of course?', Documenta Praehistorica 28, 63-73.

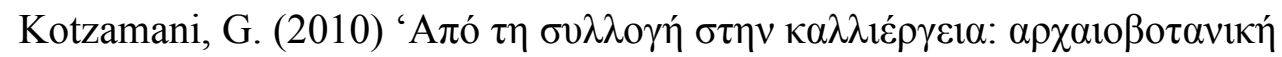

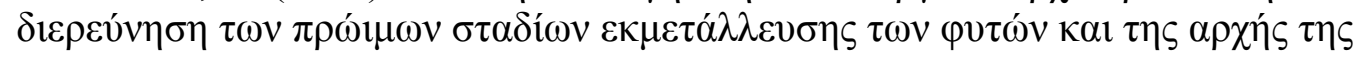

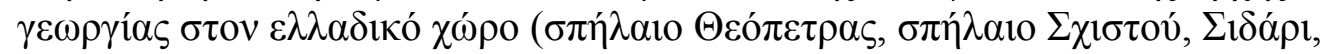

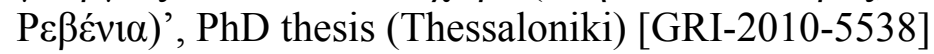

http://invenio.lib.auth.gr/collection/Theses? $\ln =\mathrm{el}$

http://phdtheses.ekt.gr/eadd/handle/10442/19671

Kroll, H. (1993) 'Kulturpflanzen von Kalapodi', Archäologischer Anzeiger 2, 16182.

Kroll, H. (2000) 'Agriculture and arboriculture in mainland Greece at the beginning of the first millennium B.C.', Pallas 52, 61-8

Livarda, A. (2008) 'The archaeobotanical remains', in E. Hatzaki, M. Prent, J.N. Coldstream, D., Evely, and A. Livarda, Knossos, The Little Palace North Project, Part I: The Early Greek Periods, Annual of the British School at Athens 103, 259-71

Livarda, A. (2012) 'The archaeobotanical evidence of the Late Bronze Age and Protogeometric occupation under the Roman Villa Dionysus, Knossos, Crete, and an overview of the Proto-geometric data of Greece', The Annual of the British School at Athens 107, 189-209

Livarda, A. and Kotzamani, G. (2014) 'The archaeobotany of Neolithic and Bronze Age Crete: synthesis and prospects', Annual of the British School at Athens 108, 1-29

Margaritis, E. (2013) 'Distinguishing exploitation, domestication, cultivation and production: the olive in the third millennium Aegean', Antiquity 87, 746-57

Margaritis, E. and Jones, M. (2008a) 'Crop processing of Olea europaea L.: an experimental approach for the interpretation of archaeobotanical olive remains', Vegetation History and Archaeobotany 17, 381-92

Margaritis, E. and Jones, M. (2008b) 'Olive oil production in Hellenistic Greece: the interpretation of charred olive remains from the site of Tria Platania, Macedonia, Greece (fourth-second century B.C.)', Vegetation History and Archaeobotany 17, 393-401

Megaloudi, F. (2005) 'Burnt sacrificial plant offerings in Hellenistic times: 
an archaeobotanical case study from Messene, Peloponnese, Greece', Vegetation History and Archaeobotany 14, 329-40

Megaloudi, F. (2006) Plants and Diet in Greece from Neolithic to Classic Periods: The Archaeobotanical Remains (British Archaeological Reports International Series 1516; Oxford)

Renfrew, C. (1972) The Emergence of Civilisation: The Cyclades and the Aegean in the Third Millennium BC (London)

Renfrew, J.M. (1968) 'Appendix X: the cereal remains', in J.D. Evans and C. Renfrew (eds) Excavations at Saliagos, near Antiparos (London), 139-41

Renfrew, J.M. (1977) 'Appendix 3: seeds from area K', in J.E. Coleman (ed) Keos I. Kephala: A Late Neolithic Settlement and Cemetery (Princeton), 127-8

Sarpaki, A. (1992) 'A palaeoethnobotanical approach. The Mediterranean triad or is it a quartet?', in B. Wells (ed) Agriculture in Ancient Greece (Stockholm), 61-76

Sarpaki, A. (1995) 'Toumba Balomenou, Chaeronia: Plant remains from the Early and Middle Neolithic levels', Res Archaeobotanicae (Kiel), 281-300.

Sarpaki, A. (1999), 'The archaeobotanical study of Tzambakas House, Rethymno, Crete', in Y. Tzedakis and H. Martlew (eds) Minoans and Mycenaeans, Flavours of their Time (Athens), 13-4, 50, 51

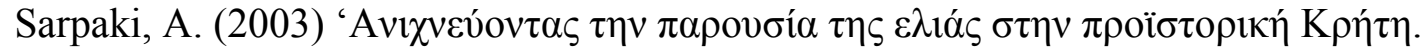

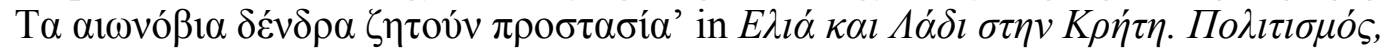

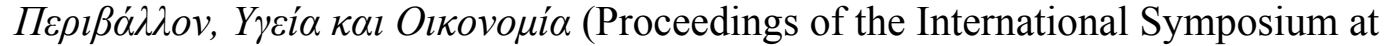
Siteia, Crete, 23-25th May 2002, Herakleion), 44-52

Sarpaki, A. (2009) 'Knossos, Crete: Invaders, "seagoers", or previously "invisible", the Neolithic plant economy appears fully-fledged in 9000 BP', in A. Fairburn and E. Weiss (eds) From Foragers to Farmers (Oxford), 220-34

Sarpaki, A. (2012a) 'The taming of an island environment: Crete from dawn to noon (Neolithic to the end of the Bronze Age)', in G. Cadogan, M. Iacovou, K. Kopaka, K. and J. Whitley (eds) Parallel Lives: Ancient Island Societies in Crete and Cyprus (London), 35-45

Sarpaki, A. (2012b) 'Re-visiting the visibility of the grape, grape products, byproducts, and some insights of its organization from the prehistoric Aegean, as guided by new evidence from Monastiraki, Crete', Interdisciplinaria Archaeologica: Natural Sciences in Archaeology 3(2), 211-20

Sarpaki, A. and Jones, G. (1990) 'Ancient and modern cultivation of Lathyrus clymenum L. in the Greek islands', Annual of the British School at Athens 85, 363-8

Schliemann, H. (1886) Tiryns. Der Prähistorische Palast der Könige von Tiryns. Ergebnisse der Neuesten Ausgrabungen (Leipzig) 
Vaiglova, P., Bogaard, A., Collins, M., Cavanagh, W., Mee, C., Renard, J., Lamb, A., Gardeisen, A. and Fraser, R. (2014) 'An integrated stable isotope study of plants and animals from Kouphovouno, southern Greece: a new look at Neolithic farming', Journal of Archaeological Science 42, 201-15

Valamoti, S.M. (2004) Plants and People in Late Neolithic and Early Bronze Age Northern Greece: an Archaeobotanical Investigation (BAR International Series, Oxford)

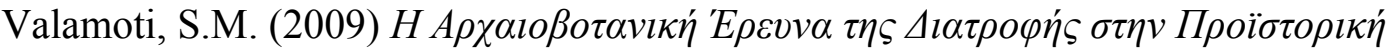
$E \lambda \lambda \dot{\alpha} \delta \alpha$ (Thessaloniki)

Valamoti, S.M. (in press) 'Millet, the late comer: on the tracks of Panicum miliaceum in prehistoric Greece', Archaeological and Anthropological Sciences (online first DOI 10.1007/s12520-013-0152-5)

Valamoti, S.M. and Kotsakis, K. (2007) 'Transitions to agriculture in the Aegean: the archaeobotanical evidence', in S. Colledge and J. Conolly (eds) the origins and spread id domestic plants in Southeast Asia and Europe (London), 75-91

Valamoti, S.M., Mangafa, M. Koukouli-Chrysanthaki, Ch. and Malamidou, D. (2007) 'Grape-pressings from northern Greece: the earliest wine in the Aegean?', Antiquity $81,54-61$

Vickery, K.F. (1936) Food in Early Greece (Chicago)

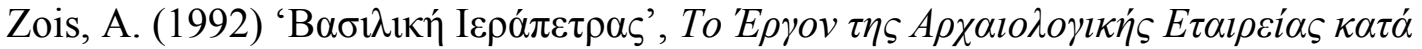
to 1991 (Athens), 109-10

Figure 01 Map of sites in Greece referred to in the text.

Figure 02 Example of a flotation machine designed for water recycling.

Figure 03 Traditional threshing floor.

Figure 04 Charred grape fruit and pip. 